\title{
Pedro de Oña. Temblor de Lima y otros poemas al Marqués de Montesclaros, Virrey del Perú (1607-1615). Sarissa Carneiro Araujo (Editora). Madrid/Frankfurt am Main: Iberoamericana/ Vervuert, 2018, 169 páginas
}

Jorge Chen Sham

Chen Sham, J. (2021). Pedro de Oña. Temblor de Lima y otros poemas al Marqués de Montesclaros, Virrey del Perú (1607-1615). Sarissa Carneiro Araujo (Editora). Madrid/Frankfurt am Main:

Iberoamericana/ Vervuert, 2018, 169 páginas. Revista de Filología y Lingüística de la Universidad de Costa Rica, 47(1), e44779. doi: https://doi.org/10.15517/rfl.v47i1.44779

\section{(9) $\mathbb{P Q \Theta \Theta}$}

Doi: https://doi.org/10.15517/rfl.v47i1.44779

URL: https://revistas.ucr.ac.cr/index.php/filyling/index 
Reseñas

Pediro de Oña. Temblor de Lima y otros poemas al Marqués

de Montesclaros, Virrey del Perú (1607-1615). Sarissa

Carneiro Araujo (Editora). Madrid/Frankfurt am Main:

Iberoamericana/ Vervuert, 2018, 169 páginas

\section{Chen Sham, Jorge}

(i) Jorge Chen Sham

jorgechsh@yahoo.com

Universidad de Costa Rica, San José, Costa Rica

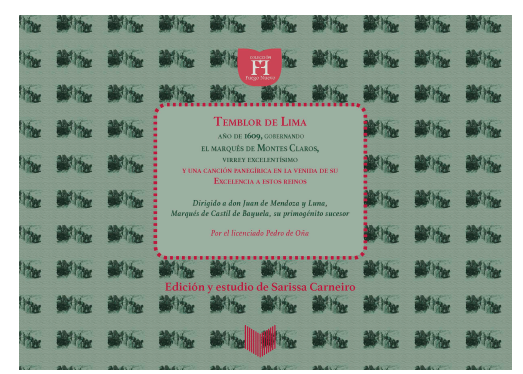

de Oña PedroCarneiro Araujo Sarissa. Temblor de Lima y otros poemas al Marqués de Montesclaros, Virrey del Perú (1607-1615).

2018. Madrid/Frankfurt am Main. Iberoamericana/ Vervuert. 169

páginaspp.

Revista de Filología y Lingüística de la Universidad de Costa Rica

Universidad de Costa Rica, Costa Rica

ISSN: 0377-628X

ISSN-e: 2215-2628

Periodicidad: Semestral

vol. 47 , núm. 1,2021

filyling@gmail.com

URL: http://portal.amelica.org/ameli,

jatsRepo/125/1251597033/index.html

DOI: https://doi.org/10.15517/rfl.v47i1.44779

El "Estudio Preliminar" (13-117) merece toda la consideración del lector, cuando se acompaña del aparato crítico y metodológico esperado para poner en realce unos textos poco conocidos todavía de la literatura colonial hispanoamericana. Y lo es porque las piezas editadas por Sarissa Carneiro Araujo se identifican con ese género por el cual, en el Antiguo Régimen, se aquilataba el valor y la fama en la república de las letras: la poesía en cualquiera de sus manifestaciones al servicio de la corte, la iglesia o el palacio: ya sea que preste sus funciones al elogio de personas o la divinidad, ya sea que se perfile como cronista de la ciudad. Sarissa 
Carneiro Araujo se dedica a trazar, con la vida y obra de Pedro de Oña, el favor y la notoriedad por los que le fueron encomendados a un "letrado" y poeta componer poemas en el Virreinato de Cuzco (16), al tiempo que pondera ese orgullo de pertenecer a esa élite que conquista y puebla las Américas por sus dos ascendientes, al servicio de la Corona y de su administración en las Indias.

Nacido en estas tierras americanas, Cervantes lo incluye en el Viaje al Parnaso entre los tres ingenios de este lado del Atlántico y Carneiro Araujo da cuenta de la polémica que suscitó su obra el Arauco domado, la cual solamente pudo publicar hasta 1605. La llegada del virrey Montesclaros, quien estuvo en el cargo de 1607 a 1613, le abre las puertas de la Corte y la "gracia" (no tan exquisita, veremos) de un mecenas, cuando Pedro de Oña compone el poema "Canción real panegírica" (24). Montesclaros lo nombra corregidor de la Provincia de Yauyos (Carneiro Araujo no indica fechas), lugar recóndito de la Corte y que no reportaba grandes entradas económicas, para ser promovido luego a un cargo similar en Vilcabamba (25) y presenciar y estar en las solemnes exequias de la reina Margarita de Austria en noviembre de 1612, ocasión para la cual compone la "Canción real".

A la figura prominente del Marqués de Montesclaros le dedica Carneiro Araujo el apartado 2 de su "Estudio preliminar" (31-42), cuyo nombre era Juan de Mendoza y Luna. Guamán Poma de Ayala en su Nueva corónica y buen gobierno, le dedica un retrato-homenaje en el que pondera su caridad cristiana y preocupación por los indios (32). Cuando termina su periodo como virrey, regresa a España y sirve a Felipe IV como consejero de Estado y Guerra (33). Carneiro Araujo se interesa por la cantidad de acusaciones y reclamos que existen en el Archivo de Indias denunciando "la corrupción y los desaciertos del virrey" (36) y, aunque se envió un visitador para investigar su caso, la influencia del Conde de Lemos cerró al final la causa. El historiador Nicolás Cabrillana pondera sus dotes como administrador en el fomento de la manufactura, el erario público y las obras públicas, sobre todo después del terremoto de 1609 , lo cual aquilató su renombre para "reconstruir una ciudad devastada por el sismo" (39). También el Marqués de Montesclaros destacó en su política indigenista a la hora de regular el trabajo en minas y otras labores de servidumbre, para lo cual remite a la historiadora Pilar Latasa, sin especificar nada en concreto (40). El Marqués también lleva a cabo una política de cercanía con el sector criollo y letrado del Virreinato, a causa de lo cual la ciudad de Lima marca un momento de esplendor cultural (41). El breve apartado 3 se dedica al género encomiástico y a la poesía panegírica (43-48), cuyo empleo socio-discursivo desemboca en la alabanza de la realeza o la nobleza, a la que el poeta rinde su pleitesía dentro del tópico grecolatino de viri ilustribus: así dentro de la sociedad colonial, la figura del virrey "concentró los máximos esfuerzos encomiásticos de los ingenios locales" (43), los cuales podían celebrar tanto sus efemérides privadas como las propias que marcaba el calendario de la Corona.

En el apartado 4 sobre la "Canción real panegírica" (1607), Sarissa Carneiro Araujo tiene razón en apuntar la importancia de la dimensión encomiástica que los festejos y otras celebraciones enaltecen y exponen: convocan tanto a la corte como a los círculos de poetas, con esa maestría y privilegio por la canción pindárica (con estrofa, antiestrofa y épodo) y dividida en varias estancias. Así, la inventio desarrolla en esa naturaleza elogiada la magnificencia del poder, porque la retórica epidíctica del panegírico eleva con sus referencias al sol y a las constelaciones, mientras no solo se les pide a los montes "de placer chocando" (v. 67) celebrar, sino también se hace referencia a los ríos en un paralelismo con un repaso a la minería de oro (56). El "cielo antártico" y austral teje una compleja y trabada alegoría, que Carneiro Araujo analiza con detalles en la "Canción real panegírica", para que su análisis pueda ser un buen ejemplo de análisis de este tipo de poemas de agudezas y de tópicos desarrollados (57) bajo la referencia a Atlas y a Hércules. Carneiro Araujo compara su dispositivo con otros poetas contemporáneos, por ejemplo, Francisco de Figueroa y Diego de Hojeda, ofreciéndonos una comparación harto pertinente, de contrastes y de filiaciones (73).

El apartado 5 se dedica al poema más conocido de Pedro de Oña, “Temblor de Lima” (1609), el cual se escribe a raíz del terremoto de Lima del 19 de octubre de 1609. El sismo produjo apenas seis muertes, pero sí muchos daños materiales en la ciudad, que el virrey debió solventar con su "industria” y dedicación, pues "el temblor [fue] escenario también para la demostración de la prudencia, justicia y liberalidad del virrey” (79). 
Rápidamente Oña escribe este poema, como si fuera una crónica poética del desastre recién vivido y que perdurará en la memoria histórica de los criollos y habitantes de la ciudad que vivieron el sismo. Poetizar las hazañas y la catástrofe en tanto evento en una poesía de carácter didáctico y a la vez bucólico permite seleccionar un modelo de prestigio como el que le ofrecía la rima de octavas del tipo ABABABCC (80). El poema inicia con una naturaleza hostil (que contrasta con lo pastoril) y un clima adverso que resuena como desencadenante del relato de las "cosas acaecidas" y que Carneiro Araujo pone dentro de la tradición de las relaciones de "sucesos extraordinarios" (84). Uno de los detalles de su comentario me llamó la atención, cuando ella expone que la visualización del desastre obedece al desarrollo de la técnica de la éckfrasis, mientras el encomio del Marqués se sujeta a la retórica de las "empresas" que desarrolla el príncipe. Pertinente y bien desarrollado para que el breve apartado 6, en donde se analiza la "Canción real" en las exequias de la reina Margarita (1612), la editora haga un manejo impecable de la tradición de las exequias reales y lo que ella denomina el "elogio oblicuo" (104), porque el objeto del panegírico se amplía al Marqués de Montesclaros, quien ha también orquestado este homenaje a su reina.

Se trata de una edición crítica de Pedro de Oña que satisface ampliamente al lector especializado, solamente esperaría una edición para que el amplio público peruano pueda acceder a unos poemas que forman parte también de su tradición colonial. 